\title{
Expression of Epstein-Barr virus in renal cell carcinoma
}

\author{
MISUZU SHIMAKAGE ${ }^{1,7}$, KUNIMITSU KAWAHARA $^{3}$, SHIZUKO HARADA $^{4}$, \\ TOSHIYUKI SASAGAWA ${ }^{5}$, TOSHIAKI SHINKA ${ }^{6}$ and TOSHITSUGU OKA ${ }^{2}$
}

\begin{abstract}
${ }^{1}$ Clinical Reseach Institute, ${ }^{2}$ Department of Urology, National Hospital Organization, Osaka National Hospital, 2-1-14 Hoenzaka, Chuo-ku, Osaka 540-0006; ${ }^{3}$ Department of Pathology, Osaka Prefectural Medical Center for Respiratory and Allergic Diseases, 3-7-1 Habikino, Habikino-City 583-8588; ${ }^{4}$ Department of Virology I, National Institute of Infectious Diseases, 1-23-1 Toyama, Shinjuku-ku, Tokyo 162-8640; ${ }^{5}$ School of Health

Sciences, Faculty of Medicine, Kanazawa University, 5-11-80 Kodatsuno 920-6942; ${ }^{6}$ Department of Urology, Wakayama Medical College, 811-1 Kimiidera, Wakayama 641-8509, Japan
\end{abstract}

Received February 1, 2007; Accepted March 12, 2007

\begin{abstract}
There have been few studies regarding the etiology of renal cell carcinoma. To examine the possible involvement of Epstein-Barr virus (EBV) in this disease, 9 renal cell carcinoma (RCC), 2 nephroblastoma (Wilms' tumor) and 2 RCC cell lines were subjected to mRNA in situ hybridization and indirect immunofluorescence staining. Messenger RNA in situ hybridization using BamHIW, EBNA LP, EBNA 2 and EBER1 probes of EBV revealed signals in all the examined samples, although some samples showed weak signals using the EBNA LP probe. Indirect immunofluorescence staining using anti-EBNA LP, anti-EBNA2, anti-LMP1 and anti-BZLF1 antibodies showed definitive fluorescence. PCR also revealed EBV DNA in all 8 RCC specimens including 7 cases other than hybridization and fluorescence. EBV infected all the RCC and nephroblastoma irrespective of the histological or clinical stage. On the other hand, EBV expression was stronger in papillary and clear cell-type RCC than chromophobe cell-type, as well as being stronger in the higher grades of RCC. These results suggest that the expression of EBV may be involved in the pathogenesis of RCC and nephroblastoma.
\end{abstract}

Correspondence to: Dr Misuzu Shimakage Present address: ${ }^{7}$ Department of Pediatrics, National Hospital Organization, Wakayama National Hospital, 1138 Wada, Mihama-Town, Hidaka-gun, Wakayama Prefecture 644-0044, Japan

E-mail: misuzu_s@wakayama2.hosp.go.jp

Abbreviations: EBV, Epstein-Barr virus; PCR, polymerase chain reaction; EBNA LP, Epstein-Barr virus nuclear antigen-leader protein; EBNA2, Epstein-Barr virus nuclear antigen-2; LMP1, latent membrane protein-1; EBER1, EBV encoded small non-polyadenylated RNAs; BZLF1, BamHIZ coding leftward reading frame-1; RCC, renal cell carcinoma

Key words: human herpesvirus 4, in situ hybridization, RCC, Wilms' tumor

\section{Introduction}

Renal cell carcinoma (RCC) accounts for 3\% of all malignancies and is the most lethal of the urologic cancers. RCCs are thought to arise primarily from the proximal convoluted tubules. Although a number of potential etiologic factors have been identified including viruses, lead compounds and chemicals, no specific agent has been established as causative in human RCC (1). In these etiologic agents, we studied EpsteinBarr virus (EBV) infection in RCC tissues, because the expression of EBV nuclear antigen 2 (EBNA2) in kidney tubule cells has been reported to induce renal tumors in transgenic mice (2).

EBV is a ubiquitous virus that infects both adults and adolescents throughout the world. It is a well-established causative agent of infectious mononucleosis, and is associated with endemic Burkitt's lymphoma, nasopharyngeal carcinoma, Hodgkin's disease and diffuse large B-cell lymphoma in immunosuppressed hosts (3). We have shown that EBV is also related to many other human cancers (4-16). In thyroid carcinoma, EBV correlates with tumor progression of papillary to undifferentiated carcinoma (12). The transforming genes of EBV are suspected to be in the regions of EBV-determined nuclear antigen-2 (EBNA2) $(17,18)$, and latent membrane protein-1 (LMP1) (19). EBNA-coding sequences commonly share the BamHIW region which is repeated approximately 10 times in an EBV genome, and the BamHIY1Y2 (EBNA LP) region. EBER1 is a non-polyadenylated RNA abundantly present in latently EBV-infected cells (20). BZLF1 protein initiates the switch from latent to lytic infection (21).

To examine the relationship between EBV and RCC, mRNA in situ hybridization, using 4 different EBV probes and indirect immunofluorescence staining using 4 different monoclonal antibodies against EBV, was performed. The BamHIW and EBNA2 probes and anti-EBNA2 and anti-LMP1 antibodies were selected to detect transformation by EBV. Furthermore, the BamHIY1Y2 (EBNA LP) probe and antiEBNA LP antibody are also probably associated with EBV transformation (16). We examined 2 cases of nephroblastoma and 2 cell lines established from RCC. The EBV DNA was also confirmed by nested PCR. 
EBV expression was detected in all RCC and nephroblastoma tissues. The results presented herein indicated that mRNAs and proteins of EBV were expressed in RCC and nephroblastoma, suggesting that EBV may be a causative agent of these disorders.

\section{Materials and methods}

Patients. Formalin-fixed paraffin-embedded tissue samples from 9 patients with RCC and 2 patients for control with renal diseases other than RCC and 1 with a bladder tumor were selected from the 1994 to 2004 files at Osaka National Hospital; 2 patients with nephroblastoma were selected from the 1994 to 2004 files at Wakayama Medical College. As a control, 2 samples of normal kidney were selected from the 2003 to 2005 autopsy files at Osaka Prefectural Medical Center for Respiratory and Allergic Diseases. The pathological classification was in accordance with the general rule indicated in previously reported literature (22). All were Japanese and none had features indicative of an immunocompromised state. Informed consent was obtained from each patient.

Probes. BamHIW probes were transcribed from $2.27 \mathrm{~kb}$ EBV BamHIW fragments from which the 'Alu-family'-like sequence had been deleted. The BamHIW fragment of EBV is a highly repetitive sequence that contains the mRNA leader sequence for EBNAs (23). The fragment was cloned into the pBluescript II $\mathrm{SK}^{+}$vector. cDNA of the BamHIY1Y2 (EBNA LP) region was also cloned into pBluescript II $\mathrm{SK}^{+}$, and the size of this cDNA was $153 \mathrm{bp}$. The antisense and sense probes were labelled with digoxigenin-11-UTP by in vitro transcription with T3 and T7 polymerases, respectively, using a commercial kit (Boehringer Mannheim, Mannheim, Germany). EBNA2 cDNA (14802-48583 including a spliced sequence) and EBER1 cDNA (6629-6795) were synthesized with RT-PCR according to the method reported by Tierney et al (24), and cloned into pGEM-T Easy Vector (Promega, Madison, WI, USA). The sizes of these cDNAs were 386 and $167 \mathrm{bp}$, respectively. The antisense and sense RNA probes were labelled with digoxigenin-11-UTP by in vitro transcription with SP6 and T7 polymerases using a commercial kit (Boehringer Mannheim). The labelled BamHIW and EBNA2 riboprobes were then fragmented to about 100 bases in length with alkaline hydrolysis. The sense probe served as a negative control.

Messenger RNA in situ hybridization. Paraffin sections were prepared from formalin-fixed tissues from biopsied or surgically resected materials. Serial sections were cut to 3-5 $\mu \mathrm{m}$. After dewaxing and dehydration with graded ethanol, slides were treated with $0.2 \mathrm{~N} \mathrm{HCl}$ for $15 \mathrm{~min}$ at room temperature (RT) and rinsed with phosphate-buffered saline (PBS) for $5 \mathrm{~min}$ at $\mathrm{RT}$, then treated with $50 \mu \mathrm{g} / \mathrm{ml}$ proteinase $\mathrm{K}$ in PBS for $15 \mathrm{~min}$ at $37^{\circ} \mathrm{C}$, and immersed in $2 \mathrm{mg} / \mathrm{ml}$ glycine in PBS for $10 \mathrm{~min}$ at RT. They were then refixed with $4 \%$ paraformaldehyde in PBS for $15 \mathrm{~min}$ at room temperature and washed twice with PBS for $3 \mathrm{~min}$ at RT, then treated with $0.1 \mathrm{M}$ triethanolamine $(\mathrm{pH} 8.0)$ for $10 \mathrm{~min}$ at RT. After washing with PBS, the sections were dehydrated with ethanol and hybridized for $40 \mathrm{~h}$ at $37^{\circ} \mathrm{C}$ for EBNA2 and EBER1, $39^{\circ} \mathrm{C}$ for Bam HIY1Y2 (EBNA LP) and at $45^{\circ} \mathrm{C}$ for BamHIW in $4 \mathrm{X} \mathrm{SSC}, 50 \%$ formamide, $1 \mathrm{X}$ Denhardt's solution, $5 \%$ dextran sulfate, $0.5 \mathrm{mg} / \mathrm{ml}$ salmon sperm DNA, $0.5 \mathrm{mg} / \mathrm{ml}$ yeast tRNA and $10 \mathrm{mM}$ dithiothreitol. After hybridization, the sections were washed twice with $2 \mathrm{X}$ SSC for $30 \mathrm{~min}$ and then twice with $0.5 \mathrm{X} \mathrm{SSC}$ for $20 \mathrm{~min}$ with gentle shaking at RT. They were then blocked with $1 \%$ skim-milk (Difco) in $100 \mathrm{mM}$ Tris, $0.15 \mathrm{M} \mathrm{NaCl}(\mathrm{pH} 7.5)$ for $30 \mathrm{~min}$ at RT. Next, they were reacted with 1:100 diluted (for EBNA2) and 1:200 diluted (for BamHIW, BamHIY1Y2 and EBER1) alkaline phosphataselabelled anti-DIG antibody (Boehringer Mannheim) in blocking buffer for $2 \mathrm{~h}$ at RT. After washing, the sections were incubated with Nitroblue tetrazolium and X-phosphate (Boehringer Mannheim) in buffer containing 0.1 M Tris, 0.1 M NaC1, $0.005 \mathrm{M} \mathrm{MgCl}_{2}$ and $1 \mathrm{mM}$ levamisole ( $\mathrm{pH} 9.6$ ) for $16 \mathrm{~h}$ at RT. Visualization was stopped with EDTA, and then the slides were dehydrated with graded ethanol and xylene, and sealed with malinol. These methods are a modified version of those previously reported by us (4-16).

Indirect immunofluorescence staining. Formalin-fixed paraffinembedded tissue samples and control specimens were cut in serial sections of 3-5 $\mu \mathrm{m}$. After dewaxing and dehydration, the sections were autoclaved in $10 \mathrm{mM}$ citrate buffer ( $\mathrm{pH}$ 6.0) for $10 \mathrm{~min}$ at $120^{\circ} \mathrm{C}$ to detect EBNA2, EBNA LP and BZLF1. Alternatively, the samples were digested for $15 \mathrm{~min}$ with proteinase $\mathrm{K}$ at a concentration of $1 \mathrm{mg} / \mathrm{ml}$ in $50 \mathrm{mM}$ Tris- $\mathrm{HCl}$ ( $\mathrm{pH}$ 7.6) at RT to detect LMP1. The sections were then blocked with 10-times-diluted EBV-negative human serum and $20 \%$ normal goat serum for $16 \mathrm{~h}$ at $4^{\circ} \mathrm{C}$. Monoclonal anti-EBNA2 antibody PE2, anti-LMP1 antibody CS1-4, anti-BZLF1 antibody (Dako, Glostrup, Denmark) and anti-EBNA LP antibody JF186 (25) were diluted 10 times with PBS and reacted for $90 \mathrm{~min}$ at $37^{\circ} \mathrm{C}$. After washing with PBS, biotinylated goat anti-mouse IgG (Vector, Burlingame, CA, USA ) was diluted 75 times with PBS and reacted for $60 \mathrm{~min}$ at $37^{\circ} \mathrm{C}$. After washing, streptavidin-fluorescein isothiocyanate conjugate (Bethesda Research Laboratory, Gaithersburg, MD, USA) diluted 200 times was reacted for $45 \mathrm{~min}$ at RT. After washing, the slides were sealed with Perma Fluor (Japan Tanner, Kobe). Negative controls with tissue samples were reacted with 10-times-diluted normal mouse IgG. These methods are identical to those we have used to study other human cancers (4-16).

Nested PCR. DNA was extracted from frozen tissues. The primers used for the 1st round of PCR were: 5'CCAGACAG CAGCCAATTCTC3' (nucleotide positions of BamHIW 1087-1106), and 5'CCTAAGAAGGCACCGGTC3' (15031520). The primers used for the 2 nd round of PCR were: 5'GTAAGAGGGGGTCTTCTAC3' (1196-1214), and 5'CCA GAGGTAAGTGGACTT3' (1399-1416). The resulting 2nd round product was $220 \mathrm{bp}$. The PCRs were carried out in a thermal cycler GeneAmp 9600-R (Perkin-Elmer). The reaction mixture contained $100 \mathrm{ng}$ to $1 \mu \mathrm{g}$ of template DNA or $10 \mathrm{ng}$ of positive control DNA (Namalwa and Raji), $0.1 \mathrm{nmol}$ of each primer, and $200 \mu \mathrm{M}$ each of dATP, dGTP, dCTP and dTTP in $1 \mathrm{X}$ amplification buffer (10 mM Tris- $\mathrm{HCl}, \mathrm{pH} 8.3$; $50 \mathrm{mM} \mathrm{KCl} ; 1.5 \mathrm{mM} \mathrm{MgCl} ; 0.01 \% \mathrm{~W} / \mathrm{V}$ gelatin) and $2.5 \mathrm{U}$ of EX Taq polymerase (Perkin-Elmer/Takara) in a total volume of $100 \mu \mathrm{l}$. The samples were treated for $5 \mathrm{~min}$ at $94^{\circ} \mathrm{C}$ 
Table I. Summary of results.

\begin{tabular}{|c|c|c|c|c|c|c|c|c|c|c|c|c|c|}
\hline \multirow[b]{2}{*}{ Diseases } & \multirow[b]{2}{*}{ Case } & \multirow[b]{2}{*}{ Histology } & \multirow[b]{2}{*}{ Grade } & \multirow[b]{2}{*}{ Age } & \multirow[b]{2}{*}{ Sex } & \multicolumn{4}{|c|}{ ISH } & \multicolumn{4}{|c|}{ IF } \\
\hline & & & & & & $B a m \mathrm{~W}^{\mathrm{d}}$ & $\mathrm{LP}^{\mathrm{e}}$ & $E 2^{f}$ & $\mathrm{E} 1^{\mathrm{g}}$ & LP & $\mathrm{E} 2$ & LMP1 & $\mathrm{BZ} 1^{\mathrm{h}}$ \\
\hline \multirow[t]{9}{*}{$\mathrm{RCC}$} & 1 & Clear cell & G1 & 41 & M & + & $\mathrm{w}+$ & + & + & - & + & +- & - \\
\hline & 2 & Clear cell & G1 & 39 & $\mathrm{~F}$ & + & $\mathrm{w}+$ & $\mathrm{w}+$ & + & +- & +- & +- & - \\
\hline & 3 & Clear cell & $\mathrm{G} 2$ & 59 & M & + & $\mathrm{w}+$ & - & + & + & +- & $\mathrm{w}+$ & w+ \\
\hline & 4 & Clear cell & G3 & 59 & $\mathrm{~F}$ & ++ & + & + & + & ++ & + & $\mathrm{w}+$ & ++ \\
\hline & 5 & Clear cell & G3 & 73 & M & ++ & + & $\mathrm{w}+$ & $\mathrm{w}+$ & + & $\mathrm{w}+$ & ++ & +- \\
\hline & 6 & $\mathrm{CC}$ with sarc ${ }^{\mathrm{a}}$ & G3 & 48 & M & ++ & + & $\mathrm{w}+$ & $\mathrm{w}+$ & ++ & + & + & +- \\
\hline & 7 & Chromophobe & $\mathrm{G} 2$ & 42 & $\mathrm{~F}$ & $\mathrm{w}+$ & - & $\mathrm{w}+$ & $\mathrm{w}+$ & - & $\mathrm{w}+$ & + & +- \\
\hline & 8 & Chromophobe & G3 & 48 & M & + & - & - & - & - & +- & + & - \\
\hline & 9 & Papillary & G3 & 53 & M & ++ & $\mathrm{w}+$ & + & + & $\mathrm{w}+$ & + & + & - \\
\hline \multirow[t]{2}{*}{ Wilms } & 1 & Nephroblastoma & & 2 & $\mathrm{~F}$ & +- & + & + & - & + & + & ++ & $\mathrm{w}+$ \\
\hline & 2 & Nephroblastoma & & $10 \mathrm{M}$ & $\mathrm{F}$ & + & ++ & + & $\mathrm{w}+$ & $\mathrm{w}+$ & $\mathrm{w}+$ & + & $\mathrm{w}+$ \\
\hline \multirow[t]{2}{*}{$\mathrm{RCC}$ lines } & & NC65 & & & & + & ++ & + & ++ & + & + & $\mathrm{w}+$ & +- \\
\hline & & ACHN & & & & + & ++ & + & + & $\mathrm{w}+$ & $\mathrm{w}+$ & $\mathrm{w}+$ & +- \\
\hline \multirow[t]{5}{*}{ Controls } & 1 & Glomerulosc ${ }^{b}$ & & 43 & $\mathrm{M}$ & +- & - & - & +- & - & +- & - & - \\
\hline & 2 & Ischemic $^{c}$ & & 59 & M & +- & - & - & +- & +- & - & - & - \\
\hline & 3 & Bladder tumor & & 68 & M & - & - & NT & NT & NT & NT & NT & NT \\
\hline & 4 & Normal kidney & & & & - & - & - & - & & & & \\
\hline & 5 & Normal kidney & & & & - & - & - & - & & & & \\
\hline
\end{tabular}

${ }^{\mathrm{a}} \mathrm{CC}$ with sarc, clear cell RCC with sarcomatoid change; ${ }^{\mathrm{b}}$ Glomerulosc, Glomerulosclerosis; ${ }^{\mathrm{C}}$ Ischemic, ischemic renal disease; ${ }^{\mathrm{d}}$ BamW, BamHIW; 'LP, EBNA LP; ${ }^{\mathrm{f} E} 2$, EBNA2; ${ }^{\mathrm{E}} \mathrm{E} 1, \mathrm{EBER} 1{ }^{\mathrm{h}} \mathrm{BZ} 1, \mathrm{BZLF} 1$; w+, weakly positive; +-, equivocal.

and amplified by 40 cycles of PCR, each consisting of $1 \mathrm{~min}$ of denaturing at $94^{\circ} \mathrm{C}, 30 \mathrm{sec}$ of annealing at $55^{\circ} \mathrm{C}$, and $1 \mathrm{~min}$ of extension at $72^{\circ} \mathrm{C}$. After treating for $10 \mathrm{~min}$ at $72^{\circ} \mathrm{C}$, the DNA was concentrated by ethanol precipitation, electrophoresed on a $1.8 \%$ agarose gel in TAE buffer (40 mM Tris$\mathrm{HCl}, \mathrm{pH} 8.0,5 \mathrm{mM}$ sodium acetate, $1 \mathrm{mM}$ EDTA) and stained with $0.5 \mu \mathrm{g} / \mathrm{ml}$ ethidium bromide. This method has already been described $(4,5,12)$.

\section{Results}

The results are summarized in Table I. In BamHIW mRNA in situ hybridization, signals were detected in the cytoplasm in all the sections hybridized with the antisense probe (Fig. 1B), but not with the sense probe or in the normal part (Fig. 1C). This result indicates that EBV infected all RCC and nephroblastoma, irrespective of histological or clinical diagnosis. Normal kidney tissues and cancer cells of bladder tumor for the negative control showed few signals with the antisense probe. In BamHIY1Y2 (EBNA LP ) mRNA in situ hybridization, signals were detected in the cytoplasm in the sections hybridized with the antisense probe (Fig. 1D), but not with the sense probe (Fig. 1E). Signals were weak in low-grade RCC, and were not observed in chromophobe cell-type RCC. In EBNA2 mRNA in situ hybridization, signals were also detected in the cytoplasm in many cases hybridized with the antisense probe (Fig. 1G), but not with the sense probe, and the signals were weak in 4 cases. In EBER1 RNA in situ hybridization, signals were detected in the nuclei in many cases that were hybridized with the antisense probe (Fig. 1H), but not with the sense probe, and the signals were weak in 4 cases. Two cell lines established from RCC also showed frequently strong hybridization signals with all these antisense probes, but not with sense probes. An example is shown in Fig. 1F.

We further examined the EBV protein expression by indirect immunofluorescence staining. Immunofluorescence staining using anti-EBNA2 antibody was prominent in the nuclei of RCC cells (Fig. 2A and B), but not in the normal region (Fig. 2C). Immunofluorescence staining using antiLMP1 antibody revealed fluorescence in the membranes of RCC cells (Fig. 2D). Immunofluorescence staining using antiEBNA LP antibody was prominent in the nuclei of RCC cells (Fig. 2E). Immunofluorescence staining using anti-BZLF1 antibody revealed fluorescence in the nuclei of RCC cells (Fig. 2F). Immunofluorescence was also observed in cases of nephroblastoma.

Hybridization signals and fluorescence were observed in all these experiments of renal cancer specimens, while normal kidney and renal diseases other than neoplasm showed few signals or fluorescence (Table I). This showed that EBV was 


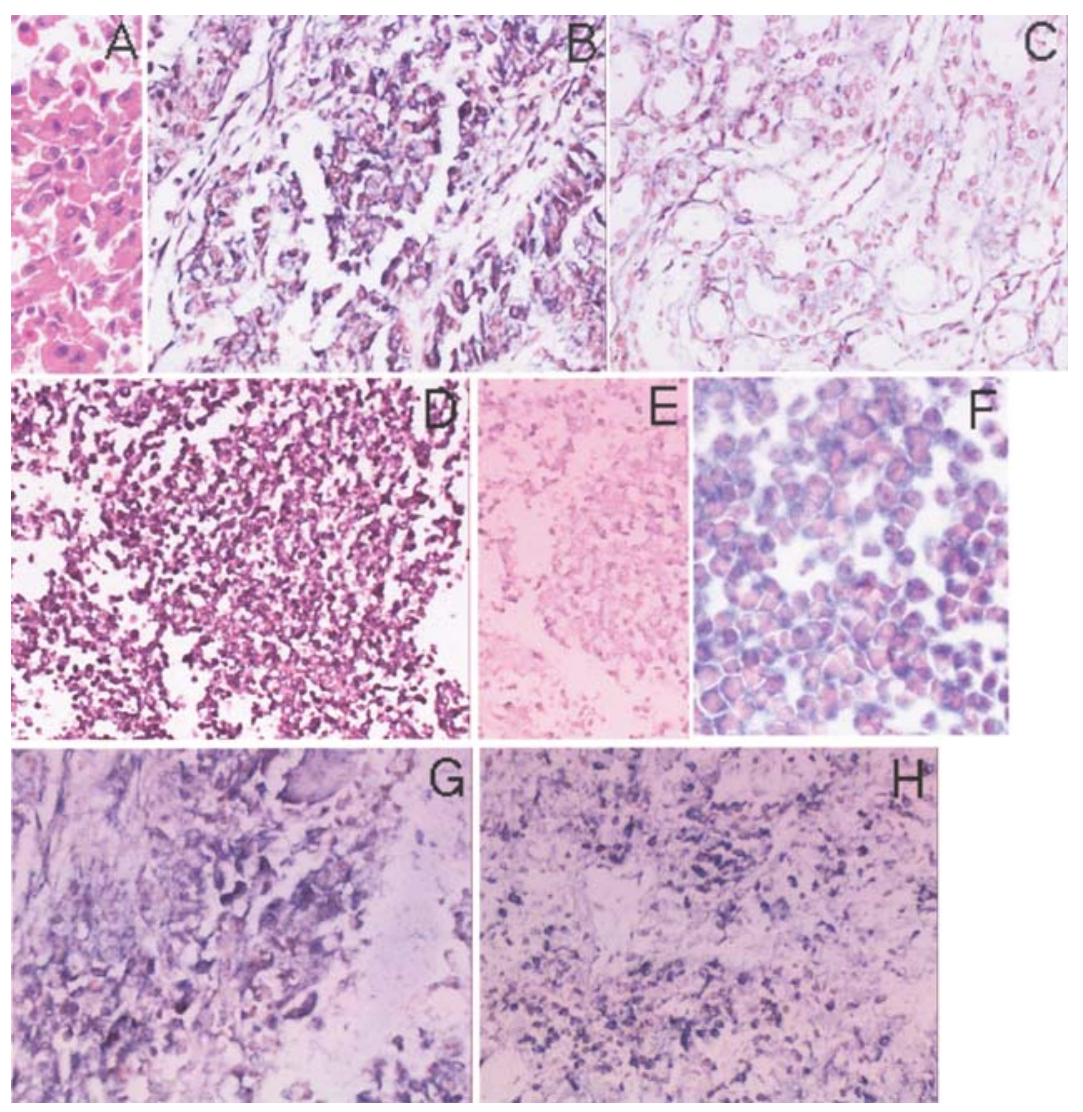

Figure 1. Results of mRNA in situ hybridization. (A) Hematoxylin-eosin staining of RCC case 9, papillary cancer area, x40; (B) mRNA in situ hybridization of RCC case 9 with BamHIW antisense probe, papillary cancer area, x40; (C) mRNA in situ hybridization of RCC case 9 with BamHIW antisense probe, normal area, $\mathrm{x} 40$. Hybridization signal was far clearer in papillary cancer area than normal area. (D) mRNA in situ hybridization of Wilms case 1 with EBNA LP antisense probe, $\mathrm{x} 40$; (E) mRNA in situ hybridization of Wilms case 1 with EBNA LP sense probe, $\mathrm{x} 40$. Hybridization signal was very weak with the sense probe. (F) mRNA in situ hybridization of RCC cell line NC65 with BamHIW antisense probe, x40; (G) mRNA in situ hybridization of RCC case 6 with EBNA 2 antisense probe, $\mathrm{x} 40$; (H) mRNA in situ hybridization of RCC case 4 with EBER 1 antisense probe, $\mathrm{x} 40$.

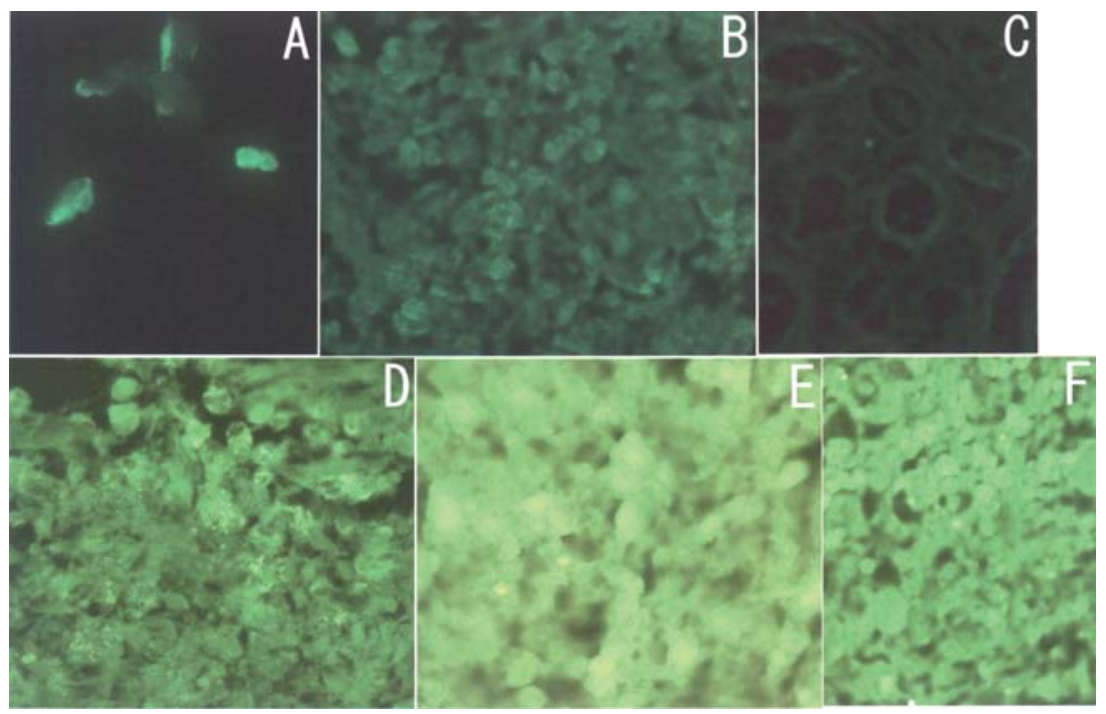

Figure 2. Results of indirect immunofluorescence. (A) Immunofluorescence with monoclonal anti-EBNA2 antibody PE2 of RCC cell line NC65, x40; (B) Immunofluorescence with monoclonal anti-EBNA2 antibody PE2 of RCC case 9, papillary carcinoma area, x40; (C) Little fluorescence was observed with the same antibody of RCC case 9, normal area, x40; (D) Immunofluorescence with monoclonal anti-LMP1 antibody CS1-4 of RCC case 5, x40; (E) Immunofluorescence with monoclonal anti-LP antibody JF186 of RCC case 4, x40; (F) Immunofluorescence with monoclonal anti-BZLF1 antibody BZ1 of RCC case 4, x40.

expressed in cells with renal cancer, but that EBV expression seldom occurred in the normal kidney or other renal diseases than RCC.
EBV DNA was detected by nested PCR. DNA was extracted from resected RCC tissues of other RCC samples than those used for in situ hybridization and immunofluore- 


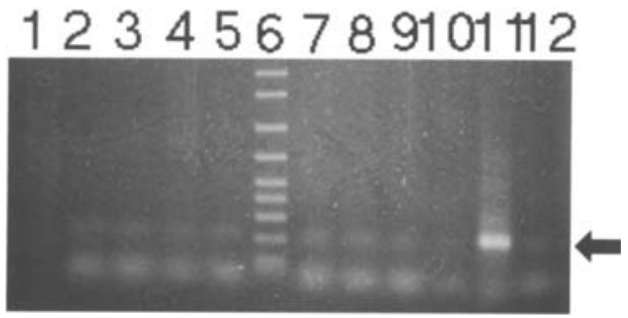

Figure 3. Results of nested PCR. Lane 1, distilled water for negative control; lane 2, clear cell RCC, G2, 52-year-old male; lane 3, chromophobe cell RCC, G2, 42-year-old female; lane 4, clear cell RCC, G2, 86-year-old female; lane 5, clear cell RCC, G2, 70-year-old male; lane 6, molecular weight marker; lane 7, clear cell RCC, G2, 48-year-old male; lane 8, clear cell RCC, G2, 57-year-old male; lane 9, clear cell RCC, G2>G3, 71-year-old male; lane 10, same as RCC case 5, clear cell RCC, G3, 73-year-old male; lane 11, EBV-carrying lymphocyte cell line Namalwa; lane 12, EBV-negative infantile tonsilla for negative control

scence except one case. EBV DNA was amplified in the region of BamHIW in all cases examined (Fig. 3).

\section{Discussion}

In this study, we showed that EBV infected all samples of RCC, nephroblastoma and RCC cell lines. This would be the first study to demonstrate a direct association of EBV with RCC. In the literature, EBV infection of renal proximal tubule cells has been described in chronic interstitial nephritis (26). The report mentioned that EDV DNA was detected in renal proximal cells by in situ hybridization using a DNA probe of Bam HIW and by PCR, and further, CD21, which is a cellular receptor of EBV, was also detected to be co-localized (26). Although RCC has not been described to occur after the course of interstitial nephritis, there may be a link between chronic interstitial nephritis and RCC, because RCC has been described to be derived from the region of proximal tubule cells (1). Inflammation and cancer have been discussed for many years $(27,28)$. We have demonstrated EBV expression in lymphoproliferative disorders in the lung, which contained long-term interstitial pneumonia, and lymphomas thought to originate from cells generated in response to various types of chronic inflammation (29). Therefore, it may be easily inferred that chronic interstitial nephritis infected with EBV causes RCC. A report on induced renal tumors in transgenic mice expressing EBNA2 in kidney tubule cells (2) also supported our supposition.

EBV expression was observed stronger in papillary and clear cell RCC than chromophobe cell RCC (Table I). Chromophobe cell RCC is described to be less malignant than other RCC (1). Further, EBV was expressed more strongly in highgrade RCC than low-grade RCC (Table I). This suggested that EBV expression correlated with RCC malignancy.

Our BamHIW probes did not contain an 'Alu-family'-like sequence, and so the reaction was considered to be specific to EBV. The antisense probe did not react with EBV-negative cells. As the BamHIW fragment of EBV contains a 10-times redundant sequence (23), this probe is very sensitive for the detection of EBV. Furthermore, the BamHIW fragment is the leader sequence of mRNAs of EBNAs, which are suspected to be oncogenes of EBV; therefore, the BamHIW probe is important for the detection of EBV transformation. Moreover, we confirmed the expression of oncogenic proteins EBNA2 and LMP1 in this study. Our results with in situ hybridization and immunofluorescence suggest an oncogenic and tumor progressive role of EBV in RCC and nephroblastoma.

Nephroblastoma occurs mostly in children, and there seems no correlation with chronic EBV infection. In this experiment, we showed EBV proliferation in RCC, nephroblastoma and RCC cell lines through the examination of immunofluorescence staining with BZLF1. Although the fluorescence was weak, both cases of nephroblastoma showed BZLF1 fluorescence. Accordingly, nephroblastoma may be induced by primary infection with EBV in the childhood. Tornell et al described that Wilms tumor is associated with the overexpression of insulin-like growth factor II (IGF-II) and that EBNA2 can induce transcription of the IGF-II gene (2); therefore, the mechanism of tumorigenesis with EBV between RCC and nephroblastoma might be different. Further study is necessary to solve this problem.

\section{Acknowledgements}

We thank Dr M. Yutsudo (Osaka University) and Dr T. Akaike (Kumamoto University) for their help during this study. This study was supported by a Grant-in-Aid for Cancer Research from the Ministry of Health, Labour and Welfare of Japan.

\section{References}

1. Novick AC and Campbell SC: Renal tumor. Chapter 75. Vol. 4. In: Campbell's Urology. 8th edition. Walsh PC, Retik AB, Vaughan ED, et al (eds). WB Saunders Co., Philadelphia, PA, pp2672-2731, 2002.

2. Tornell J, Farzad S, Espander-Jansson A, Matejka G, Isaksson O and Rymo L: Expression of Epstein-Barr nuclear antigen 2 in kidney tubule cells induces tumors in transgenic mice. Oncogene 12: $1521-1528,1996$.

3. Rickinson $\mathrm{AB}$ and Kieff E: Epstein-Barr virus. Chapter 75. In: Fields Virology. 3rd edition. Fields BN, Knipe DM, Howley PM, et al (eds). Lippincott-Raven Publishers, Philadelphia, PA, pp2397-2446, 1996.

4. Shimakage M, Dezawa T, Tamura S, et al: A Ki-1-positive cell line expressing Epstein-Barr virus antigens established from a child with Ki-1-positive lymphoma. Intervirology 36: 215-224, 1993.

5. Shimakage M, Oka T, Shinka T, Kurata A, Sasagawa T and Yutsudo M: Involvement of Epstein-Barr virus expression in testicular tumors. J Urol 156: 253-257, 1996.

6. Shimakage M, Nakamine H, Tamura S, Takenaka T, Yutsudo M and Hakura A: Detection of Epstein-Barr virus transcripts in anaplastic large-cell lymphomas by mRNA in situ hybridization. Hum Pathol 28: 1415-1419, 1997.

7. Shimakage M, Sasagawa T, Yoshino K, et al: Expression of Epstein-Barr virus in mesopharyngeal and hypopharyngeal carcinomas. Hum Pathol 30: 1071-1076, 1999.

8. Sasagawa T, Shimakage M, Nakamura M, Sakaike J, Ishikawa H and Inoue M: Epstein-Barr virus (EBV) genes expression in cervical intraepithelial neoplasia and invasive cervical cancer: a comparative study with human papillomavirus (HPV) infection. Hum Pathol 31: 318-326, 2000.

9. Shimakage $M$ and Sasagawa T: Detection of Epstein-Barr virusdetermined nuclear antigen-2 mRNA by in situ hybridization. $\mathrm{J}$ Virol Meth 93: 23-32, 2001.

10. Shimakage M, Sasagawa T, Kawahara K, Yutsudo M, Kusuoka H and Kozuka T: Expression of Epstein-Barr virus in cutaneous Tcell lymphoma including mycosis fungoides. Int $\mathrm{J}$ Cancer 92: 226-231, 2001

11. Shimakage M, Horii K, Tempaku A, Kakudo K, Shirasaka T and Sasagawa T: Association of Epstein-Barr virus with oral cancers. Hum Pathol 33: 608-614, 2002.

12. Shimakage M, Kawahara K, Sasagawa T, et al: Expression of Epstein-Barr virus in thyroid carcinoma correlates with tumor progression. Hum Pathol 34: 1170-1177, 2003. 
13. Shimakage M, Sasagawa T, Kimura M, et al: Expression of Epstein-Barr virus in Langerhans' cell histiocytosis. Hum Pathol 35: 862-868, 2004.

14. Shimakage M: Langerhans cell histiocytosis and its relationship with Epstein-Barr virus - reply. Hum Pathol 37: 1509-1511, 2006.

15. Nakajima H, Shimakage M, Takeda Y, et al: Epstein-Barr virusassociated primary leptomeningeal lymphoma. Eur J Neurol 13: E4-E6, 2006

16. Shimakage M, Harada S, Kawahara K, et al: Detection of Epstein-Barr virus nuclear antigen leader protein expression in various human cancers. Chapter 9. In: New Developments in Epstein-Barr Virus Research. Umar CS (ed). Nova Science Publishers, New York, pp261-276, 2006.

17. Hammerschmid W and Sugden B: Genetic analysis of immortalizing functions of Epstein-Barr virus in human B lymphocytes. Nature 340: 393-397, 1989.

18. Shimakage M, Kurata A, Inoue H, Okamoto Y, Yutsudo M and Hakura A: Tumorigenicity of EBNA2-transfected cells. FEBS Lett 371: 245-248, 1995.

19. Wang D, Liebowitz D and Kieff E: An EBV membrane protein expressed in immortalized lymphocytes transformes established rodent cells. Cell 43: 831-840, 1985.

20. Rosa MD, Gottlieb E, Lerner MR and Steitz JA: Striking similarities are exhibited by two small Epstein-Barr virus-coded ribonucleic acids and adenovirus-associated ribonucleic acids VAI and VAII. Mol Cell Biol 1: 785-796, 1981.
21. Miller G: The switch between latency and replication of Epstein-Barr virus. J Infect Dis 161: 833-844, 1990.

22. Eble JN, Sauter G, Epstein JI and Sesterhenn IA (eds): Pathology and genetics of tumours of the urinary system and male genital organs. World Health Organization of Tumours. IARC Press, Lyon, 2004.

23. Cheung A and Kieff E: Long internal direct repeat in EpsteinBarr virus DNA. J Virol 44: 286-294, 1982.

24. Tierney RJ, Steven N, Young LS and Rickinson AB: EpsteinBarr virus latency in blood mononuclear cells, analysis of viral gene transcription during primary infection and in the carrier state. J Virol 68: 7374-7385, 1994.

25. Finke J, Rowe M, Kallin B, et al: Monoclonal and polyclonal antibodies against Epstein-Barr virus nuclear antigen 5 (EBNA-5) detect multuple protein species in Burkitt's lymphoma and lymphoblastoid cell lines. J Virol 61: 3870-3878, 1987.

26. Becker JL, Miller F, Nuovo GJ, Josepovitz C, Schubach WH and Nord EP: Epstein-Barr virus infection of renal proximal tubule cells: possible role in chronic interstitial nephritis. J Clin Invest 104: 1673-1681, 1999.

27. Balkwill $\mathrm{F}$ and Manntovani A: Inflammation and cancer: back to Virchow? Lancet 357: 539-545, 2001

28. Coussens LM and Werb Z: Inflammation and cancer. Nature 420: 860-867, 2002.

29. Shimakage M, Sakamoto H, Harada S, Sasagawa T and Kodama K: Expression of the Epstein-Barr virus in lymphoproliferative diseases of the lung. Oncol Rep 17: 1347-1352, 2007 